DE

M E D I C I N A

T R O P I C A L

$\mathrm{DE}$

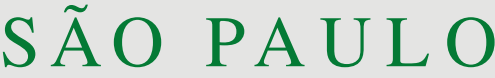

JOURNAL OF THE SÃO PAULO INSTITUTE OF TROPICAL MEDICINE

${ }^{1}$ Universidade Federal de Goiás, Instituto de Patologia Tropical e Saúde Pública, Goiânia, Goiás, Brazil

2Universidade Federal de Goiás, Faculdade de Farmácia, Goiânia, Goiás, Brazil

Correspondence to: Maria do Rosário Rodrigues Silva

Universidade Federal de Goiás, Instituto de Patologia Tropical e Saúde, Rua 235, esquina $\mathrm{c} / 1^{\mathrm{a}}$ Avenida, $\mathrm{s} / \mathrm{n}^{\circ}, 3^{\circ}$ andar, Sala 426, Setor Universitário, CEP 74605-050, Goiânia, GO, Brazil

Tel: +55 62 99436-4242.

E-mail: rosario@ufg.br

Received: 23 May 2018

Accepted: 20 August 2018

\section{Antifungal potential of punicalagin against Cryptococcus neoformans species complex}

\author{
Thaísa Cristina Silva ${ }^{1}$, Ana Laura de Sene Amâncio Zara ${ }^{1}$, Fabyola Amaral \\ da Silva Sá ${ }^{2}$, Maria Teresa Freitas Bara², Renato Ivan de Ávila², Carolina \\ Rodrigues Costa', Marize Campos Valadares ${ }^{2}$, Andressa Santana dos \\ Santos', Vivianny Aparecida Queiroz Freitas', Maria do Rosário Rodrigues \\ Silva ${ }^{1}$
}

\section{ABSTRACT}

This study evaluated the antifungal activity and cytotoxicity profile of the ellagitannin punicalagin, a compound extracted from the L. pacari A.St.-Hil (Lythraceae) leaf, against Cryptococcus neoformans species complex. Minimum inhibitory concentrations (MIC) were checked using the broth microdilution method. Minimum fungicidal concentrations (MFC) and time of death were used to confirm the antifungal activity of the compound. The in vitro cytotoxicity of punicalagin was tested in BALB/c3T3 fibroblasts and A549 human lung cancer cell line, while the hemolytic potential was tested on sheep erythrocytes. The morphological changes induced in yeast strains by the presence of punicalagin were also analyzed. Tested on eight isolates of the C. neoformans complex punicalagin showed MIC of 0.5 to $4.0 \mu \mathrm{g} / \mathrm{mL}$ and MFC $>256 \mu \mathrm{g} / \mathrm{mL}$. Punicalagin also demonstrated a good growth inhibitory activity in time-kill curves, but it was not able to achieve a statistically significant reduction of fungal growth suggesting a fungistatic effect of the compound. In vitro cytotoxicity studies using the two cell lines showed that punicalagin has low activity on these cells and no activity on sheep erythrocytes. Morphological changes were seen in the yeasts strains studied when treated with punicalagin. Therefore, punicalagin is a potential antifungal for important pathogenic yeasts and presents a low cytotoxicity profile associated with no hemolytic effects.

KEYWORDS: Punicalagin. Lafoensia pacari A.St.-Hil. Cytotoxicity. Antifungal activity. Cryptococcus neoformans species Complex

\section{INTRODUCTION}

Punicalagin extracted from Lafoensia pacari A. St.-Hil (Lythraceae) is a compound that has medicinal properties ${ }^{1}$. Lafoensia pacari is a plant known in Brazil as dedaleiro ou pacari. In folk medicine, it is used as wound healing, antipyretic, antidiarrheal, and in the treatment of gastritis, ulcers and cancer ${ }^{2,3}$. The ellagitannin punicalagin has shown activity against Cryptococcus neoformans species complex, dermatophytes and some species of Candida ${ }^{4-7}$.

Cryptococcosis is a severe systemic mycosis, with worldwide distribution ${ }^{8}$, and its prevalence is estimated to be more than one million cases with about 650,000 deaths annually ${ }^{9}$. Infections caused by Cryptococcus gattii have a protracted course of illness ${ }^{10}$, and it is well known that $C$. gattii isolates are significantly less susceptible to azoles than the isolates of $C$. neoformans ${ }^{11,12}$. This fungal infection is mainly associated with resistance to available antifungal drugs ${ }^{13}$. Therefore, the 
development of new products showing broad spectrum of action against cryptococcal species with low toxicity are extremely necessary.

Thus, the present study aims to evaluate the antifungal activity andthe cytotoxicity of punicalagin, a phenolic compound extracted from $L$. pacari leaf against C. neoformans species complex, as well morphological change analyses induced in yeast strains by the presence of punicalagin.

\section{MATERIALS AND METHODS}

Leaves from L. pacari A. St.-Hil (Lythraceae) were submitted to ultrasound extraction with acetone:water (70:30) and punicalagin was characterized by HPLC/UV and ESI-TOF MS, 1D and 2D NMR spectroscopic evaluations as described by Carneiro et al. ${ }^{1}$.

The yeast strains used in this study were: $C$. neoformans ATCC 28957, C. gattii ATCC 24065, six clinical isolates of $C$. neoformans species complex obtained from patients with meningitis in a tertiary hospital of Goiania, Goias State, Brazil (three C. gattii - L1, L9, and L20 and three Cryptococcus neoformans - L3, L29, and L30). These isolates were collected in a previous study approved by the Bioethics Committee of Hospital de Doenças Tropicais de Goias (protocol 027/07).

\section{Microdilution broth assay}

The in vitro activity of punicalagin was measured by means of the microdilution broth method, according to the Clinical and Laboratory Standards Institute (CLSI) guidelines M27-A3 (CLSI 2012 $2^{14}$ ) and M27- S4 (CLSI 2012 ${ }^{15}$ ) for yeasts. Serial twofold dilutions of the pure compound were prepared in 96-well microplates. The minimal inhibitory concentration (MIC) was defined as the lowest concentration that resulted in the total inhibition growth analyzed by visual inspection, giving a numerical score in comparison with the growth present in the control (drug-free) sample.

The minimal fungicidal concentration (MFC) was determined by an inoculum of $10 \mu \mathrm{L}$ from each well containing the MIC and up to $4 \times$ MIC seeded in petri plates containing Sabouraud dextrose agar (SDA), incubated for $72 \mathrm{~h}$ at $35{ }^{\circ} \mathrm{C}$. The MFC was defined as the lowest concentration of the compound that resulted in growth of less than two colonies representing the death of $>99 \%$ of the original inoculum. Fluconazole was used as the control.

\section{Time kill assay}

Cell growth and death rates of the yeast strains studied were analyzed according to the modified protocols of Klepser et al. ${ }^{16}$ and Silva et al. ${ }^{17}$. Dilutions of $1 / 10$ in RPMI-1640 (Sigma Chemical Co., St. Louis, MO, USA) of broth suspension containing approximately 1 to $5 \times 10^{6} \mathrm{CFU} / \mathrm{mL}$ were prepared in order to obtain the initial concentration of 1 to $5 \times 10^{5} \mathrm{CFU} / \mathrm{mL}$. Punicalagin was added to this suspension solutions to obtain a final concentration of $1 / 2$ MIC ( $2 \mu \mathrm{g} / \mathrm{mL})$, MIC $(4 \mu \mathrm{g} / \mathrm{mL})$, and $2 \times$ MIC $(8 \mu \mathrm{g} / \mathrm{mL})$ of this compound. Test solutions were placed on a shaker and incubated at $35^{\circ} \mathrm{C}$. At predetermined time points $(0,6,12,24,48$ and $72 \mathrm{~h})$, following the introduction of the test isolate, $100 \mu \mathrm{L}$ of samples were removed from each test solution. Tenfold serial dilutions ( $10^{-2}$ to $10^{-5}$ on RPMI-1640 broth) were performed using samples and aliquots of $10 \mu \mathrm{L}$ of each dilution, plated in $\mathrm{SDA}$ and the number of $\mathrm{CFU}$ on each plate was determined. Kill curve assays were run in duplicate.

\section{Cytotoxicity assays}

\section{Cell cultures}

The BALB/c 3T3 A31 fibroblasts and A549 human lung cells were cultured in DMEM and Ham's F12 nutrient mixture, respectively, supplemented with heatinactivated FBS $(10 \%$, v/v), HEPES $(4.5 \mathrm{mM})$, sodium bicarbonate $(0.17 \mathrm{M})$, L-glutamine $(2 \mathrm{mM})$, in a humidified atmosphere of $5 \% \mathrm{CO}_{2}$ in air at $37^{\circ} \mathrm{C}$. When cells reached approximately $70 \%$ confluence, they were harvested with a trypsin $(0.025 \%) /$ EDTA $(0.02 \%)$ solution. Cell viability was tested using the $\mathrm{TC} 20^{\mathrm{TM}}$ automated cell counter (Hercules, CA, USA), according to manufacturer's instructions, and a value $>90 \%$ was considered satisfactory to conduct the assays.

\section{$3 T 3$ neutral red uptake (NRU) assay}

The 3T3 NRU assay was performed according to the standard protocol of Borenfreund and Puerner ${ }^{18}$, modified by ICCVAM ${ }^{19}$. In brief, 3 T3 fibroblasts cells containing $3 \times 10^{4}$ cells/well were treated with nine different concentrations of punicalagin ranging of $0.78-200 \mu \mathrm{g} / \mathrm{mL}$ in complete medium for $48 \mathrm{~h}$. Amphotericin B in concentrations ranging from 78 to $200 \mu \mathrm{g} / \mathrm{mL}$ ) was used as reference drug. After incubation, the supernatant was removed and the cells were washed with PBS followed by addition of neutral red $(0.25 \mathrm{mg} / \mathrm{mL})$ and incubated for $3 \mathrm{~h}$. After that, $100 \mu \mathrm{L}$ of a developing solution (50 ethanol: 1 acetic acid: 49 ultrapure water) were added to all wells, and shaken for $20 \mathrm{~min}$ at $45 \mathrm{~g}$. Absorbance was measured at $550 \mathrm{~nm}$ in a spectrophotometer (Thermo Scientific Multiskans Spectrum, Boston, MA, USA). A concentrationresponse curve was obtained to determine the concentration 
of punicalagin or amphotericin B that inhibited cell growth by $50 \%$ compared to the untreated group $\left(\mathrm{IC}_{50}\right)$.

\section{MTT assay of A549 human lung cells}

Cytotoxicity analysis in A549 cells was performed using the MTT reduction test, adapted from Mosmann ${ }^{20}$. Briefly, A549 cells $\left(1 \times 10^{5}\right.$ cells $\left./ \mathrm{mL}\right)$ were seeded in 96-well plates overnight and then treated with nine different concentrations of punicalagin $(0.78-200 \mu \mathrm{g} / \mathrm{mL})$ in complete medium for $45 \mathrm{~h}$. Amphotericin B $(0.78-200 \mu \mathrm{g} / \mathrm{mL})$ was used as reference drug. Subsequently $10 \mu \mathrm{L}$ of MTT $(5 \mathrm{mg} / \mathrm{mL})$ were added to each well, incubated for $3 \mathrm{~h}$, the supernatant was removed and $100 \mu \mathrm{L}$ of DMSO was added to each well. Absorbance was measured at $560 \mathrm{~nm}$. Cell viability was expressed as a percentage of the control $\mathrm{IC}_{50}$ and selectivity index (SI ) values were determined.

\section{Hemolytic assay}

Hemolytic assays were performed according to He et al. ${ }^{21}$. Briefly, $100 \mu \mathrm{L}$ aliquots of sheep erythrocytes/ PBS $10 \%$ were added to $100 \mu \mathrm{L}$ of a two-fold dilution series of punicalagin in concentrations ranging from 256 to $1 \mu \mathrm{g} / \mathrm{mL}$ or of amphotericin B ranging from 8 to $0.031 \mu \mathrm{g} / \mathrm{mL}$ in the same buffer and placed in Eppendorf tubes. The tubes were incubated for $30 \mathrm{~min}$ at $37{ }^{\circ} \mathrm{C}$, and centrifuged for $5 \mathrm{~min}$ at $4500 \mathrm{~g}$. From the supernatant fluid, $150 \mu \mathrm{Lwere}$ transferred to a flat bottom microtiter plate and absorbance was measured using a spectrophotometer. Total hemolysis was achieved with a $1 \%$ Triton X-100 solution.

\section{Scanning electron microscopy}

Scanning electron microscopy (SEM) analysis was performed according to Faganello et al..$^{22}$ with some modifications. The isolates were cultured in SDA containing a corresponding concentration to MIC $(4 \mu \mathrm{g} / \mathrm{mL})$ of punicalagin and incubated at $30{ }^{\circ} \mathrm{C}$. Small blocks of each fungal sample were withdrawn and fixed in $2 \%$ glutaraldehyde and $2 \%$ paraformaldehyde, in $0.1 \mathrm{M}$ sodium cacodylate buffer with $3 \%$ sucrose at $\mathrm{pH} 7.2$ and kept overnight at $4{ }^{\circ} \mathrm{C}$.

Samples were washed in the same buffer four times, dehydrated in ethyl alcohol and dried in a critical $\mathrm{CO}_{2}$ point (Autosamdri ${ }^{\circledR}$, 815, Series A) covered with gold (Denton Vacuum, Desk V) and analyzed in Jeol, JSM-6610 Scanning electron microscopy.

\section{Statistical analysis}

Data were expressed as mean or mean \pm standard deviation (SD) in cytotoxicity assays. The intergroup variation was measured by one-way analysis of variance (ANOVA) followed by Bonferroni's test using the GraphPad Prism 5.01 software (GraphPad Inc., San Diego, CA, USA). Statistical significance was established as $p<0.05$. All experiments were performed in three independent assays.

\section{RESULTS}

\section{Broth microdilution assay}

Punicalagin showed antifungal activity on species of the $C$. neoformans complex with a MIC range of 0.5 to $4.0 \mu \mathrm{g} / \mathrm{mL}$ and MFC $>256 \mu \mathrm{g} / \mathrm{mL}$ for all isolates. At the concentration of $0.5 \mu \mathrm{g} / \mathrm{mL}$ the compound inhibited $37 \%$ of the C. neoformans species complex isolates. Fluconazole showed a MIC range of 0.5 to 8.0 and a MFC range of 1 to $64 \mu \mathrm{g} / \mathrm{mL}$.

\section{Time kill curve}

The time-kill curve (Figures 1A and 1B) showed reduction in the number of $\mathrm{CFU} / \mathrm{mL}$ of the $C$. neoformans complex cells treated with punicalagin at concentrations corresponding to the MIC of $4 \mu \mathrm{g} / \mathrm{mL}$ and $2 \times$ MIC $(8 \mu \mathrm{g} / \mathrm{mL})$. The major reduction was observed with C. neoformans ATCC 28957 at a concentration corresponding to $2 \times$ MIC at $12 \mathrm{~h}$. The difference was not statistically significant between treated and non-treated cells. Amphotericin B had maximum fungicidal activity after $12 \mathrm{~h}$ of incubation at concentrations equivalent to $1 \mu \mathrm{g} / \mathrm{mL}$ for C. gattii ATCC 24065 and C. neoformans ATCC 28957.

\section{Citotoxicity using BALB/C 3T3 cells and A 549 cells}

NRU analysis showed IC50 of $58.7 \mu \mathrm{g} / \mathrm{mL}$ for punicalagin and $<0.78 \mu \mathrm{g} / \mathrm{mL}$ for amphotericin $\mathrm{B}$. Increased inhibition of $3 \mathrm{~T} 3$ cell growth was observed with enhanced concentration of punicalagin as shown in Figure 2A.

MTT analysis on alveolar epithelial cells showed that the concentration of punicalagin that caused the death of $50 \%$ of these cells was $>200 \mu \mathrm{g} / \mathrm{mL}$, while for amphotericin B, used as a cytotoxicity control, the IC was $59.6 \mu \mathrm{g} / \mathrm{mL}$. Effects of different punicalagin concentrations after 48 hours exposure are shown in Figure 2B.

\section{Hemolysis of sheep erythrocytes}

The hemolytic effect of punicalagin was tested on sheep erythrocytes and the concentration of $256 \mu \mathrm{g} / \mathrm{mL}$ produced hemolysis in $2.46 \%$ of cells, while for amphotericin B, 
A

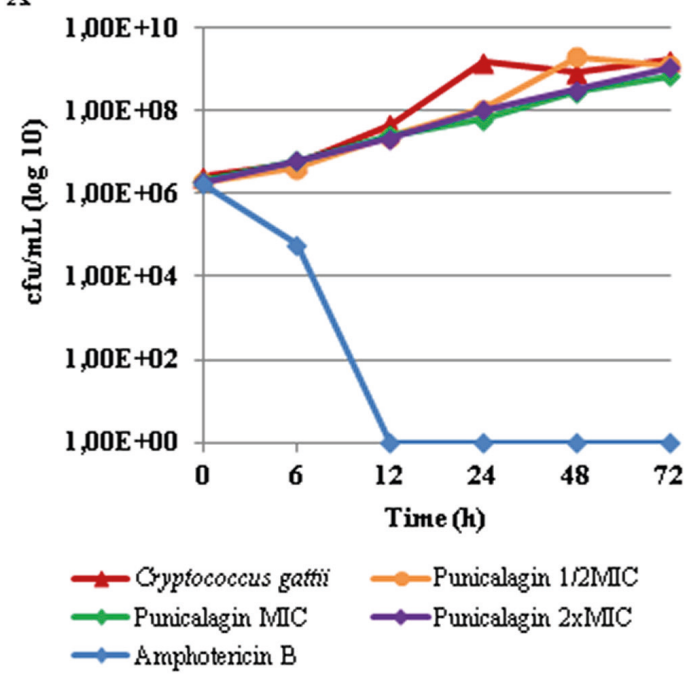

B

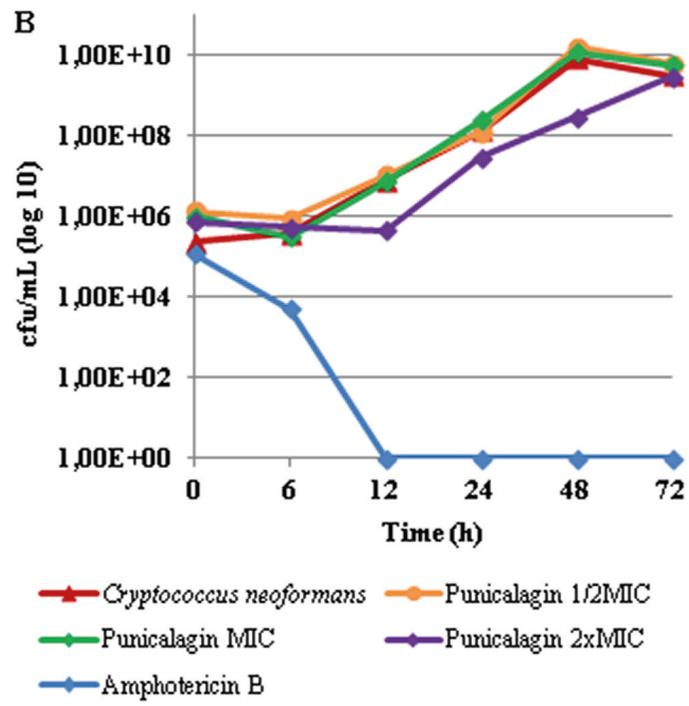

Figure 1 - Growth curve of C. gattii ATCC 24065 (A) and C. neoformans ATCC 28957 (B) without treatment and treated with punicalagin at the values corresponding to $1 / 2$ of the minimum inhibitory concentration - MIC $(0.25), \mathrm{MIC}(0.5 \mu \mathrm{g} / \mathrm{mL})$, and $2 \times \mathrm{MIC}$ $(1 \mu \mathrm{g} / \mathrm{mL})$, and amphotericin B in MIC $(0.5 \mu \mathrm{g} / \mathrm{mL})$ after $6,12,24,48$, and $72 \mathrm{~h}$ of incubation (A and B). For C. gattii ATCC 24065 , (ANOVA $p=0.481$ ) and for $C$. neoformans ATCC 28957, (ANOVA $p=0.461$ )

$\mathbf{A}$

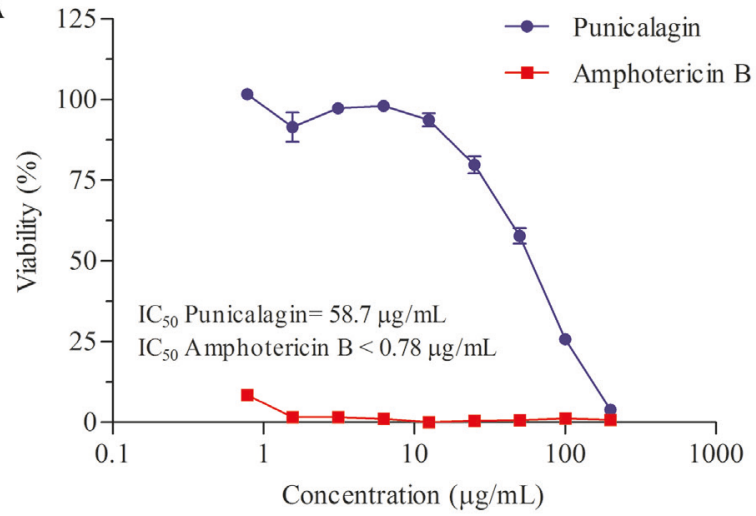

B

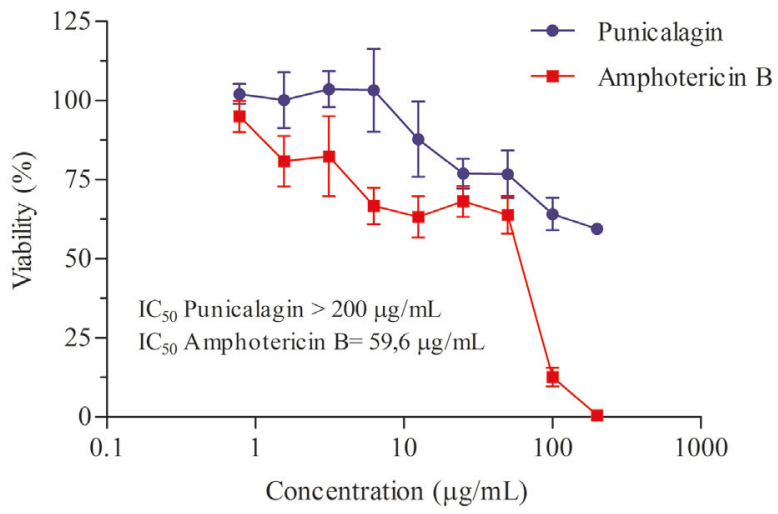

Figure 2 - A) Viability of BALB/c3T3 cells exposed with different concentrations of punicalagin and amphotericin B (both at $0.78-200 \mu \mathrm{g} / \mathrm{mL}$ ) for $48 \mathrm{~h}$ using 3T3 neutral red uptake (NRU) assay; B) Cell viability curve of human alveolar epithelium A549 at different concentrations of punicalagin and amphotericin B (both at $0.78-200 \mu \mathrm{g} / \mathrm{mL}$ ) for $48 \mathrm{~h}$ using the MTT assay

hemolysis of $0.87 \%$ of erythrocyte cells was found at concentration of $8 \mu \mathrm{g} / \mathrm{mL}$.

\section{Scanning electron microscopy}

This analysis demonstrated that the untreated cells of C. neoformans ATCC 28957 (Figure 3A) and C. gattii 24065 (Figure 3C) showed normal cell morphology with intact smooth wall and spherical bodies present in large amounts. After exposure to punicalagin, the yeasts had rough walls and were shrivel as shown in Figures $3 \mathrm{~B}$ and 3D.

\section{DISCUSSION}

Several antifungal agents have been used for the prophylaxis and treatment of Cryptococcus neoformans species complex infections ${ }^{23}$. Current pharmacological treatments are effective, but intrinsically resistant species are emerging rapidly. In addition, the high cost of treatment and host-associated cytotoxicity makes it necessary to search for new microbial compounds. The activity of punicalagin has been studied against some Candida species and against $C$. neoformans $s^{4,6,7,24}$ but there are no reports described for $C$. gattii. Interestingly, the isolate $C$. gattii L20 showed high MIC value to fluconazole, with low MIC value for punicalagin. Fluconazole is the drug of choice for the maintenance therapy of cryptococcal disease ${ }^{25}$.

Moreover, our findings have shown that punicalagin promotes fungistatic effects. CFM was $>256$ for all isolates and although the kill curve showed reduction in the numbers of CFU of yeast cells, this difference was not statistically significant in treated and untreated cells for all yeasts 


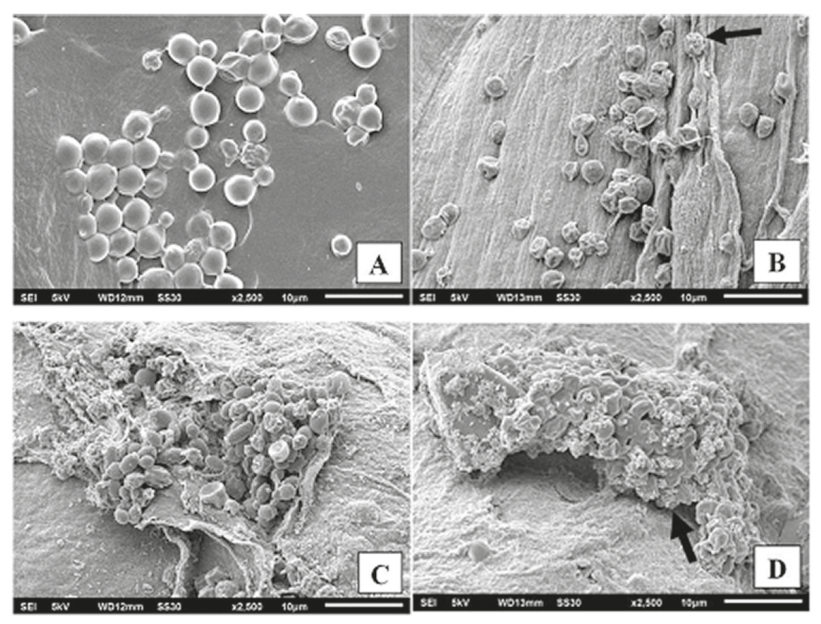

Figure 3 - Cell morphology analysis of $C$. neoformans ATCC 28957 and C. gattii 24065. Untreated cells appear ovoid and intact ( $A$ and $C$ ); and cells treated with punicalagin at minimum inhibitory concentration - MIC $(4 \mu \mathrm{g} / \mathrm{mL})$ show rough and shrivel yeasts $(B$ and $D)$

studied (ANOVA). Our results are similar to those found by Endo et al. ${ }^{6}$, who found a small reduction of CFU in the presence of punicalagin. Fungistatic effects of naturally occurring tannins against yeasts were reported by BabaMoussa et al. ${ }^{26}$ and Morey et al. ${ }^{27}$. The extract of Terminalia avicennioides stem bark was fungicidal on Epidermophyton floccosum, Microsporum gypseum and Trichophyton mentagrophytes, but only fungistatic on Trichophyton rubrum and Candida albicans (Baba-Moussa et al. ${ }^{26}$ ). Fraction of Stryphnodendron adstringens exhibited a fungistatic effect with the minimum inhibitory concentration ranging from 0.5 to $8.0 \mu \mathrm{g} / \mathrm{mL}$ in Candida tropicalis (Morey et al. ${ }^{27}$ ).

In this study, we found that punicalagin has low toxic activity on human lung carcinoma A549 cells, 3T3 fibroblast cells, and no hemolytic potential to animal cells. The concentration of punicalagin with 50\% cytotoxicity (IC50) on BALB/c 3T3 cells was $58.7 \mu \mathrm{g} / \mathrm{mL}$, showing that this compound was 14.6 times greater than their MIC $(4 \mu \mathrm{g} / \mathrm{mL})$ against yeasts. Similar results were found with carcinoma cells, where IC50 was $200 \mu \mathrm{g} / \mathrm{mL}$, therefore, 50-fold larger than the MIC. Similar data to this study confirm the results of low in vitro toxicity observed for punicalagin. The low cytotoxic activity of punicalagin was verified by Endo et al. ${ }^{6}$ on Vero and macrophages J774G8 cell monolayers and Foss et al. ${ }^{5}$ on Vero cells.

We have also demonstrated that punicalagin exhibited low toxicity on sheep erythrocytes cells. Lysis of sheep erythrocytes cells is easily obtained by measuring the release of hemoglobin, constituting a good tool for toxicity studies. Determination of hemolysis activity is quick, reproducible, and inexpensive ${ }^{28}$.

The reduced number of cells with rough and shrivel yeasts in the presence of punicalagin indicated that the compound caused damage to the cell structure. These alterations could represent the first step towards the discovery of new drugs. Compounds that inhibit microbial growth and cause morphological changes can be proposed as potential antifungal agents.

Based on the data obtained, we believed that punicalagin has antifungal potential on important pathogenic yeasts and presents a low cytotoxicity profile associated with no hemolytic potential to animal cells. The excellence of punicalagin suggests that it may be a promising drug against yeasts and invites further research.

\section{CONFLICT OF INTERESTS}

The authors declare no conflicts of interest.

\section{FUNDING}

The authors would like to thank the Coordenação de Aperfeiçoamento de Pessoal de Nível Superior (CAPES) and Conselho Nacional de Desenvolvimento Científico e Tecnológico $(\mathrm{CNPq})$ for the financial support, process $\mathrm{N}^{\circ}$ 454660/2014-6.

\section{REFERENCES}

1. Carneiro CC, Santos SC, Lino Jr RS, Bara MT, Chaibub BA, Reis $\mathrm{PR}$, et al. Chemopreventive effect and angiogenic activity of punicalagin isolated from leaves of Lafoensia pacari A. St.-Hil. Toxicol Appl Pharmacol. 2016;310:1-8.

2. Solon S, Lopes L, Sousa Jr PT, Schmeda-Hirschmann G. Free radical scavenging activity of Lafoensia pacari. J Ethnopharmcol. 2000;72:173-8.

3. Mundo SR, Duarte MR. Morfoanatomia foliar e caulinar de dedaleiro: Lafoensia pacari A. St.-Hil. (Lythraceae). Lat Am J Pharm. 2007;26:522-9.

4. Anibal PC, Peixoto IT, Foglio MA, Höfling JF. Antifungal activity of the ethanolic extracts of Punica granatum L. and evaluation of the morphological and structural modifications of its compounds upon the cells of Candida spp. Braz J Microbiol. 2013;44:839-48.

5. Foss SS, Nakamura CV, Ueda-Nakamura T, Cortez DA, Endo EH, Dias Filho BP. Antifungal activity of pomegranate peel extract and isolated compound punicalagin against dermatophytes. Ann Clin Microbiol Antimicrob. 2014;13:32.

6. Endo EH, Cortez DA, Ueda-Nakamura T, Nakamura CV, Dias Filho BP. Potent antifungal activity of extracts and pure compound isolated from pomegranate peels and synergism with fluconazole against Candida albicans. Res Microbiol. 2010;161:534-40. 
7. Reddy MK, Gupta SK, Jacob MR, Khan SI, Ferreira D. Antioxidant, antimalarial and antimicrobial activities of tanninrich fractions, ellagitannins and phenolic acids from Punica granatum L. Planta Med. 2007;73:461-7.

8. Maziarz EK, Perfect JR. Cryptococcosis. Infect Dis Clin North Am. 2016;30:179-206.

9. Park BJ, Wannemuehler KA, Marston BJ, Govender N, Pappas PG, Chiller TM. Estimation of the current global burden of cryptococcal meningitis among persons living with HIV/AIDS. AIDS. 2009;23:525-30.

10. Chen SC, Slavin MA, Heath CH, Playford EG, Byth K, Marriott $\mathrm{D}$, et al. Clinical manifestations of Cryptococcus gattii infection: determinants of neurological sequelae and death. Clin Infect Dis. 2012;55:789-98.

11. Hagen F, Illnait-Zaragozi MT, Bartlett KH, Swinne D, Geertsen $\mathrm{E}$, Klaassen $\mathrm{CH}$, et al. In vitro antifungal susceptibilities and amplified fragment length polymorphism genotyping of a worldwide collection of 350 clinical, veterinary, and environmental Cryptococcus gattii isolates. Antimicrob Agents Chemother. 2010;54:5139-45.

12. Alfouzan W, Al-Sheridah S, Alenzi L, Hagen F, Meis JF, Khan Z. Cryptococcus gattii genotype AFLP6/VGII meningoencephalitis in an immunocompetent Filipino male in Kuwait: activation of a dormant infection. JMM Case Rep. 2015;2:e00058

13. Sanglard D. Emerging threats in antifungal-resistant fungal pathogens. Front Med (Lausanne). 2016;3:11.

14. Clinical and Laboratory Standards Institute. M27-A3: reference method for broth dilution antifungal susceptibility testing of yeasts: approved standard. $3^{\text {rd }}$ ed. Wayne: CLSI; 2008.

15. Clinical and Laboratory Standards Institute. M27-S4: reference method for broth dilution antifungal susceptibility testing of yeasts: $4^{\text {th }}$ informacional supplement. Wayne: Clinical and Laboratory Standards Institute; 2012.

16. Klepser ME, Wolfe EJ, Jones RN, Nightingale CH, Pfaller MA. Antifungal pharmacodynamic characteristics of fluconazole and amphotericin B tested against Candida albicans. Antimicrob Agents Chemother. 1997;41:1392-5

17. Silva DC, Martins MA, Szeszs MW, Bonfietti LX, Matos D, Melhem MS. Susceptibility to antifungal agents and genotypes of Brazilian clinical and environmental Cryptococcus gattii strains. Diagn Microbiol Infect Dis. 2012;72:332-9.
18. Borenfreund E, Puerner JA. A simple quantitative procedure using monolayer cultures for cytotoxicity assays (HTD/NR-90). J Tissue Cult Methods. 1985;9:7-9.

19. Interagency Coordinating Committee on the Validation of Alternative Methods. Current status of in vitro test methods for identifying ocular severe irritants and corrosives. Research Triangle Park: NIH; 2006. [cited 2018 Aug 22]. Available from: https://ntp.niehs.nih.gov/iccvam/docs/ocutox_docs/oteval/ otevalrpt.pdf

20. Mosmann T. Rapid colorimetric assay for cellular growth and survival: application to proliferation and cytotoxicity assays. J Immunol Methods. 1983;65:55-63.

21. He M, Du M, Fan M, Bian Z. In vitro activity of eugenol against Candida albicans biofilms. Mycopathologia. 2007;163:137-43.

22. Faganello J, Arruda W, Schrank A, Vainstein MH. An alternative method to prepare samples of the pathogenic yeast Cryptococcus neoformans for scanning electron microscopy analysis. J Microbiol Methods. 2006;64:416-9.

23. Pianalto K, Alspaugh J. New horizons in antifungal therapy. J Fungi. 2016; 2:1-24.

24. Liu M, Katerere DR, Gray AI, Seidel V. Phytochemical and antifungal studies on Terminalia mollis and Terminalia brachystemma. Fitoterapia. 2009;80:369-73.

25. Saag MS, Graybill RJ, Larsen RA, Pappas PG, Perfect JR, Powderly WG, et al. Practice guidelines for the management of cryptococcal disease. Clin Infect Dis. 2000;30:710-8.

26. Baba-Moussa F, Akpagana K, Bouchet P. Antifungal activities of seven West African Combretaceae used in traditional medicine. J Ethnopharmacol. 1999;66:335-8.

27. Morey AT, Souza FC, Santos JP, Pereira CA, Cardoso JD, Almeida RS, et al. Antifungal activity of condensed tannins from Stryphnodendron adstringens: effect on Candida tropicalis growth and adhesion properties. Curr Pharm Biotechnol. 2016;17:365-75.

28. Mapfunde S, Sithole S, Mukanganyama S. In vitro toxicity determination of antifungal constituents from Combretum zeyheri. BMC Complement Altern Med. 2016;16:162. 